\title{
Satellite DNA sites in four species of the genus Astyanax (Teleostei, Characiformes)
}

\author{
Karine Frehner Kavalco ${ }^{1}$, Rubens Pazza $^{2}$, Luiz Antonio Carlos Bertollo ${ }^{3}$ and Orlando Moreira-Filho ${ }^{3}$ \\ ${ }^{1}$ Departamento de Genética e Biologia Evolutiva, Instituto de Biociências, Universidade de São Paulo, \\ São Paulo, SP, Brazil. \\ ${ }^{2}$ Grupo de Pesquisas em Biodiversidade e Conservação, Centro Universitário Nove de Julho, São Paulo, \\ SP, Brazil. \\ ${ }^{3}$ Departamento de Genética e Evolução, Universidade Federal de São Carlos, São Carlos, SP, Brazil.
}

\begin{abstract}
Cytogenetic data about satellite DNA distribution in four Astyanax species (Characidae) from the Paraitinga river, Paraíba do Sul river basin, Brazil, are presented. In order to characterize the constitutive heterochromatin, C-banding, chromomycin $\mathrm{A}_{3}$ and DAPI fluorescence staining, as well as fluorescence in situ hybridization (FISH) with the satellite DNA As-51 probe were performed. A. scabripinnis and $A$. parahybae presented $2 n=50$ and $2 n=48$ chromosomes, respectively. The heterochromatin was located in the pericentromeric and terminal regions of many chromosomes, corresponding to GC-positive regions and to the As- 51 satellite DNA in terminal regions. A. intermedius and $A$. giton, both with $2 \mathrm{n}=50$ chromosomes, showed little heterochromatin, mostly restricted to the terminal and pericentromeric regions of a few chromosomes. No GC-positive regions, neither any correspondence between the scarce heterochromatin of these species and the As-51 satellite DNA was observed. AT-positive blocks were not detected in any of the species studied. Based on these and other available data, the hypothesis that Astyanax represents a polyphyletic group is discussed.
\end{abstract}

Key words: Astyanax, fluorescence in situ hybridization (FISH), heterochromatin, karyotypic diversity, satellite DNA.

Received: February 3, 2006; Accepted: November 24, 2006.

\section{Introduction}

Astyanax, popularly known as lambaris or piabas, comprises around 74 species distributed from southern United States to northern Argentina (Eigenmann, 1921). In a recent review, about 90 valid species were considered insertae sedis in Characidae (Reis et al., 2003). Many of these species inhabit stream headwaters, including highly irregular regions (such as mountain ranges) where the headwaters of the Paraitinga river (Paraíba do Sul river basin, Brazil) are located. Morphological analyses led Weitzman and Malabarba (1998) to propose the genus polyphyly, which was corroborated by the study of $5 \mathrm{~S}$ rDNA sites distribution (Kavalco et al., 2004a).

Chromosome variability in Astyanax species reflects their ecological and genetic characteristics. It comprises variations in diploid numbers $(2 \mathrm{n}=36$ to $2 \mathrm{n}=50$ chromosomes), karyotypical macrostructure, occurrence of natural

Send correspondence to Karine Frehner Kavalco. Departamento de Genética e Biologia Evolutiva, Instituto de Biociências, Universidade de São Paulo, Rua do Matão 277, Edifício André Dreyfus, Cidade Universitária, 05508090 São Paulo, SP, Brazil. E-mail: kavalco@biociencia.org. polyploidy, presence of B-chromosomes, constitutive heterochromatin polymorphisms, and nucleolar organizer regions (NORs) distribution. Based on these features, at least three "species complexes" can be recognized: $A$. scabripinnis (Moreira-Filho and Bertollo, 1991), $A$. altiparanae (Fernandes and Martins-Santos, 2005) and $A$. fasciatus (Pazza et al., 2006).

Constitutive heterochromatin corresponds to repetitive regions in the genome which are extremely condensed during the cell cycle and have been claimed to have no transcriptional activity. Heterochromatin has played an important role in the study of the diversification of some fish groups, as in the genera Brycon (Margarido and Galetti Jr., 1999) and Leporinus (Galetti Jr. et al., 1991; Molina et al., 1998; Margarido and Galetti Jr., 2000). In these genera, the karyotypic macrostructure is relatively constant, but the heterochromatin differs between species (Galetti Jr. et al., 1991). In the Astyanax scabripinnis species complex (Moreira-Filho and Bertollo, 1991), heterochromatin polymorphisms were useful in the identification of some populations (Mantovani et al., 2000). 
Chromosome banding has been extensively used to study the distribution and nature of constitutive heterochromatin in fishes. The use of base-specific fluorochromes, such as chromomycin $\mathrm{A}_{3}$ and DAPI, has helped to characterize the composition of the constitutive heterochromatin (GC-, AT-positive or devoid of GC or AT clusters). The occurrence of GC-positive heterochromatin sequences adjacent to or interspersed among NORs has been described for many organisms (Mayr et al., 1985; Schmid and Guttenbach, 1988; Phillips and Hartley, 1988; Sola et al., 1992; Kavalco et al., 2004b). GC-positive heterochromatin not associated with NORs are very rare among fishes (Souza et al., 1996; Artoni et al., 1999; Margarido and Galetti Jr., 2000; Kavalco et al., 2004b). AT-positive regions are also quite uncommon among fishes and have mainly been reported among some Hypostominae species (Artoni and Bertollo, 1999).

Fluorescence in situ hybridization (FISH) used to locate DNA sequences has provided more accurate information on the genomic organization of several organisms. In fish, the hybridization of rDNA probes and of satellite DNAs has provided insights into the relationship among species and their karyotypic diversification (Almeida-Toledo et al., 2002; Ferro et al., 2001; Jesus et al., 2003; Kavalco and Moreira-Filho, 2003; Kavalco et al., 2004a; Kavalco et al., 2005; Martins and Galetti Jr., 1999; Mestriner et al., 2000; Pazza et al., 2005; Vicente et al., 2004).

Satellite DNA consists of many tandem repeats of identical or related short basic repeats. The As-51 satellite DNA is a multimeric fragment of $51 \mathrm{pb}$ obtained by KpnI restriction enzyme digestion of Astyanax scabripinnis samples. The As-51 satellite DNA seems to have similarities with a portion of the Anopheles gambiae RT2 retroposon, suggesting it could have arisen from a mobile element (Mestriner et al., 2000). FISH revealed that the As-51 repetitive DNA family was located in a small portion of the $A$. scabripinnis genome, distributed in all the distal C-bands (Mestriner et al., 2000).

Aiming to compare the nature and distribution of constitutive heterochromatin in four Astyanax species ( $A$. scabripinnis, A. parahybae, A. intermedius and A. giton) from the Paraíba do Sul river basin, C-banding, chromomycin $\mathrm{A}_{3}$ and DAPI staining, and FISH with the As-51 satellite DNA probe were performed. This is the first report on the nature and distribution of heterochromatin in $A$. intermedius and $A$. giton of the chromomycin $\mathrm{A}_{3}$ staining in A. parahybae and of As-51 satellite DNA distribution in $A$. intermedius, $A$. giton and $A$. parahybae. Constitutive heterochromatin data for $A$. scabripinnis are compared with previous reports.

\section{Material and Methods}

Four Astyanax species were analyzed. Six $A$. scabripinnis specimens (all female) were collected from the Macacos river (22 $50,050^{\prime} \mathrm{S}, 44^{\circ} 50^{\prime} 940^{\prime}$ Wo), nine $A$. parahybae specimens (6 males and 3 females) and $28 \mathrm{~A}$. intermedius specimens ( 2 males and 26 females) from the Paraitinga river $\left(22^{\circ} 52,225^{\prime} \mathrm{S}, 44^{\circ} 51,041^{\prime} \mathrm{Wo}\right)$. A total of 21 A. giton specimens were collected in two different sites, three males and ten females in the Paraitinga river $\left(22^{\circ} 52,225^{\prime} \mathrm{S}, 44^{\circ} 51,041^{\prime} \mathrm{Wo}\right)$, and three males, four females and a sexually undetermined specimen in the Jacuí stream $\left(23^{\circ} 02,436^{\prime} \mathrm{S}, 44^{\circ} 56,103^{\prime} \mathrm{Wo}\right)$, both part of the Paraíba do Sul river basin. The samples were identified and deposited in the ichthyological collection of the National Museum of Rio de Janeiro (Museu Nacional do Rio de Janeiro - Brazil), under the registration OMNRJ REG 20020417.

Mitotic chromosomes were obtained according to Bertollo et al. (1978). C-banding, chromomycin $\mathrm{A}_{3}$ and DAPI staining were performed according to Sumner (1972), Schmid (1980) and Schweizer (1980), respectively. Fluorescent in situ hybridization (FISH) with the As-51 satellite DNA probe was performed according to Pinkel et al. (1986), with high stringency washes and control experiments. The As-51 probe isolated from A. scabripinnis (Mestriner et al., 2000) was labeled with biotinilated uridine (BdUTP) according to the Nick Translation Bionick Labeling System Kit protocol (Invitrogen $\left({ }^{\circledR}\right)$. The detection was performed with avidin-FITC and biotin-conjugatedanti-avidin. The slides were mounted with Vectashield Mounting Medium, (Vector $\left.{ }^{\circledR}\right)$ with propidium iodide $(1.5 \mu \mathrm{g} / \mathrm{mL})$. The preparations were analyzed under a Olympus BX50 epifluorecent microscope and the images were captured (with a $1 \mathrm{Mp}$ resolution) with the CoolSnap Pro and the Image Pro Plus softwares (Media Cybernetics). The chromosomes were classified according to their arm ratios, as M-metacentric; SM-submetacentric; ST-subtelocentric; and A-acrocentric (Levan et al., 1964).

\section{Results}

All species presented heterochromatin distributed in pericentromeric or distal chromosome regions. Astyanax scabripinnis presented $2 \mathrm{n}=50$ and a karyotypic formula composed of $8 \mathrm{M}+20 \mathrm{SM}+8 \mathrm{ST}+14 \mathrm{~A}$. In this species, C-banding revealed constitutive heterochromatin in the pericentromeric regions of several chromosomes, and in the terminal regions of the long arms of pairs 1, 2, 7, 14 and 21; a submetacentric pair had an almost entirely heterochromatic short arm (Figure 1-a). Chromomycin $\mathrm{A}_{3}$ staining showed three GC-positive sites: two in the terminal region of the short arm of a subtelocentric chromosome pair and one in the long arm of a submetacentric chromosome (Figure 2-a). No AT-positive heterochromatin was observed (data not shown). One subtelocentric and two acrocentric chromosome pairs and a single submetacentric chromosome presented conspicuous terminal signals after fluorescence in situ hybridization with the pAs-51 probe (Figure 3-a). 


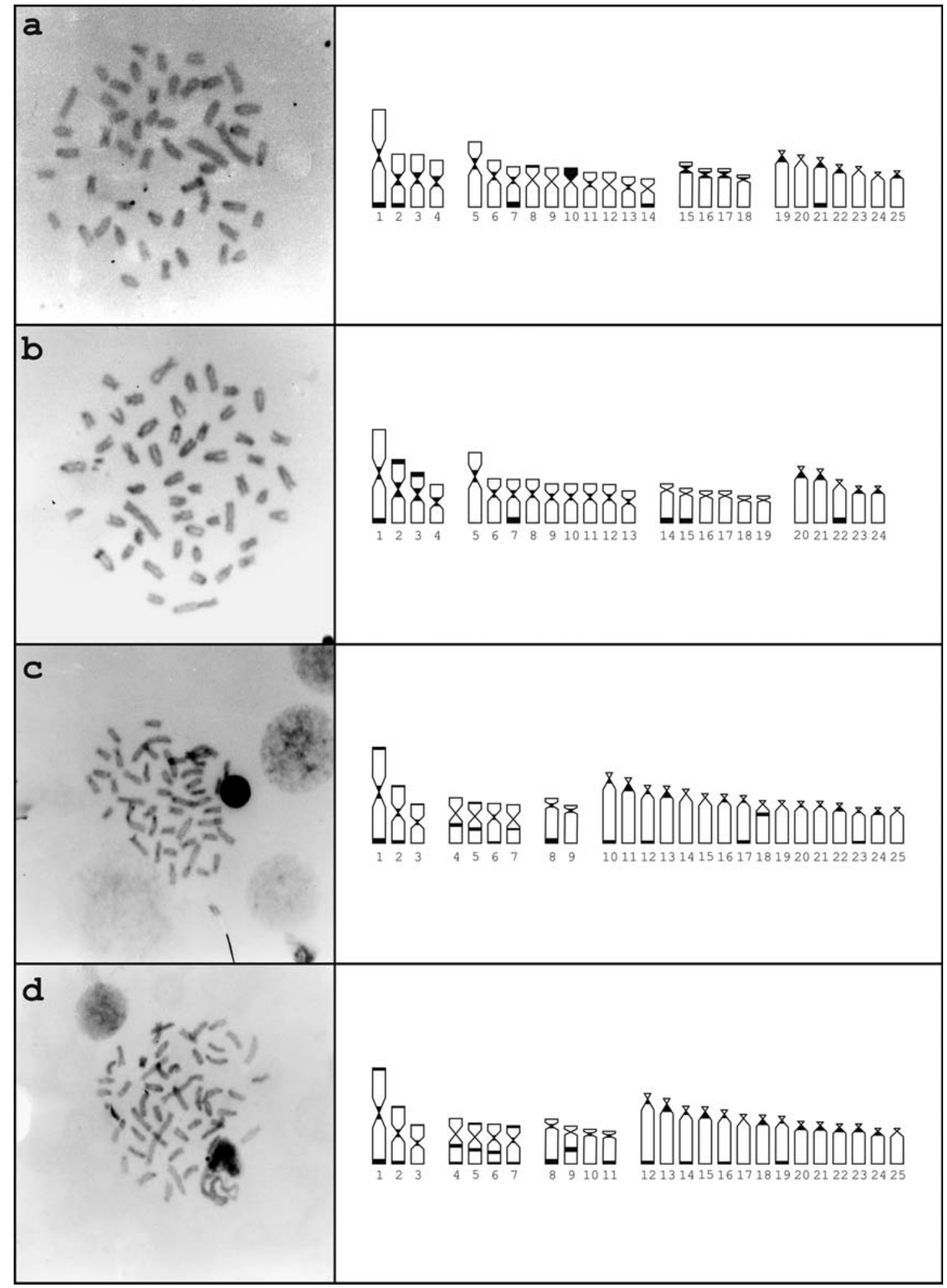

Figure 1 - C-banding metaphases and ideograms of (a) A. scabripinnis; (b) A. parahybae; (c) A. intermedius; and (d) A. giton.

Astyanax parahybae showed $2 \mathrm{n}=48$ chromosomes, with the karyotypic formula $\mathrm{M}+18 \mathrm{SM}+12 \mathrm{ST}+10 \mathrm{~A}$. C-banding revealed constitutive heterochromatin in the pericentromeric regions and in the terminal position of the long arms of chromosome pairs 1, 7, 14, 15 and 16, and in the short arms of chromosomes 2 and 3 (Figure 1-b). GC-positive regions were detected in the terminal region of the short arm of a single large metacentric chromosome and of a medium-sized metacentric pair (Figure 2-b). No ATpositive heterochromatin was observed (data not shown). 

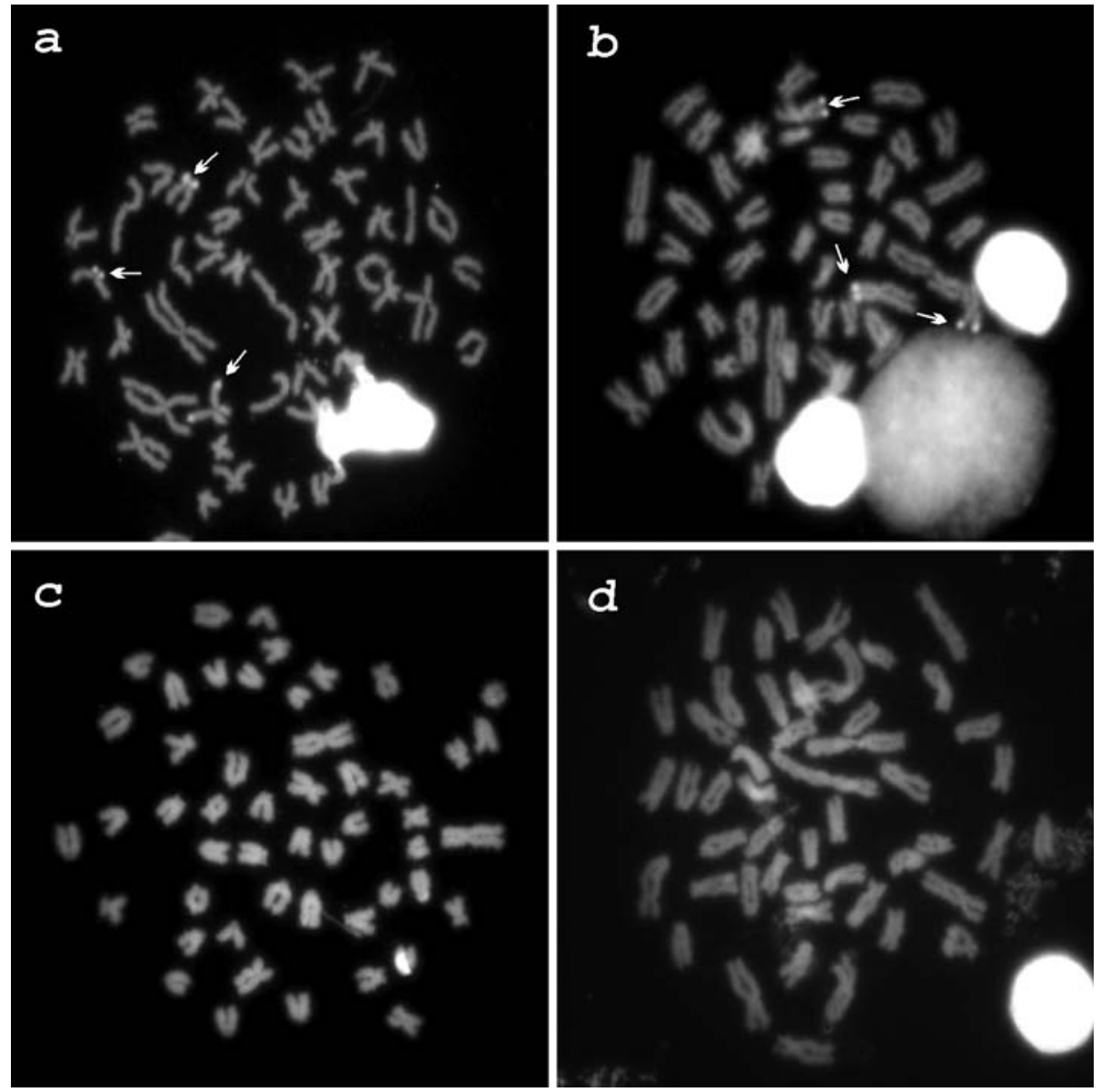

Figure 2 - Chromomycin $\mathrm{A}_{3}$ stained metaphases evidencing GC-positive regions in (a) A. scabripinnis; and (b) A. parahybae, and the absence of these sites in (c) A. intermedius; and (d) A. giton.

The As-51 satellite DNA was terminally located in two small chromosome pairs, one metacentric and one subtelocentric-acrocentric. In a few cells, an additional signal was observed in the interstitial region of the long arm of a single acrocentric chromosome (Figure 3-b).

Astyanax intermedius presented $2 \mathrm{n}=50$ and a $6 \mathrm{M}+$ $8 \mathrm{SM}+4 \mathrm{ST}+32 \mathrm{~A}$ karyotypic formula. The heterochromatin was located in the pericentromeric region of many chromosomes and in the terminal region of chromosome pairs 1, 2, 8, 10, 12, 17 and 23 (Figure 1-c). Interstitial positive C-bands were observed in chromosomes 4, 5 and 18 . No GC (Figure 2-c), AT- (data not shown) or As-51 satellite DNA sites were observed (Figure 3-c).

Astyanax giton showed $2 \mathrm{n}=50$ and a karyotype composed of $6 \mathrm{M}+8 \mathrm{SM}+8 \mathrm{ST}+28 \mathrm{~A}$ in both populations studied. $\mathrm{C}$-banding revealed heterochromatin in the pericentromeric regions of many chromosomes and in interstitial regions of chromosomes 4, 5, 6 and 9 (Figure 1-d). The interstitial band in the ninth pair is more conspicuous than the corresponding band in the $A$. intermedius karyotype. As in $A$. intermedius, no GC- (Figure 2-d), AT (data not shown) or As-51 satellite DNA sites were observed (Figure 3-d).

\section{Discussion}

Astyanax is an interesting group for cytogenetic studies, as it comprises species with distinct evolutionary trends leading towards either karyotypic conservation or diversification. The macrokaryotypic diversification that occurs in species from the "A. scabripinnis" and "A. fasciatus" complexes extends to heterochromatin variation, with frequent heteromorphisms on the nature and location of C-bands among populations, individuals and homologues (Moreira-Filho and Bertollo, 1991; Souza et al., 1996; Mantovani et al., 2000; Fernandes and Martins-Santos, 2005; Abel et al., 2006; among others). No heteromorphisms were observed in the A. scabripinnis population herein studied (Figure 1-a), possibly due to the small sample. Its GCpositive heterochromatin distribution was similar to the one reported for other populations from the Tietê river basin (Souza et al., 1996). The exceptions were the single chromosome with a fluorescence signal, an exclusive trait of the population herein analyzed (Figure 2-a), and the distribution of the As-51 satellite DNA (Figure 3-a), less abundant than in the populations from the upper Paraná river basin (Mantovani et al., 2004; Abel et al., 2006). 

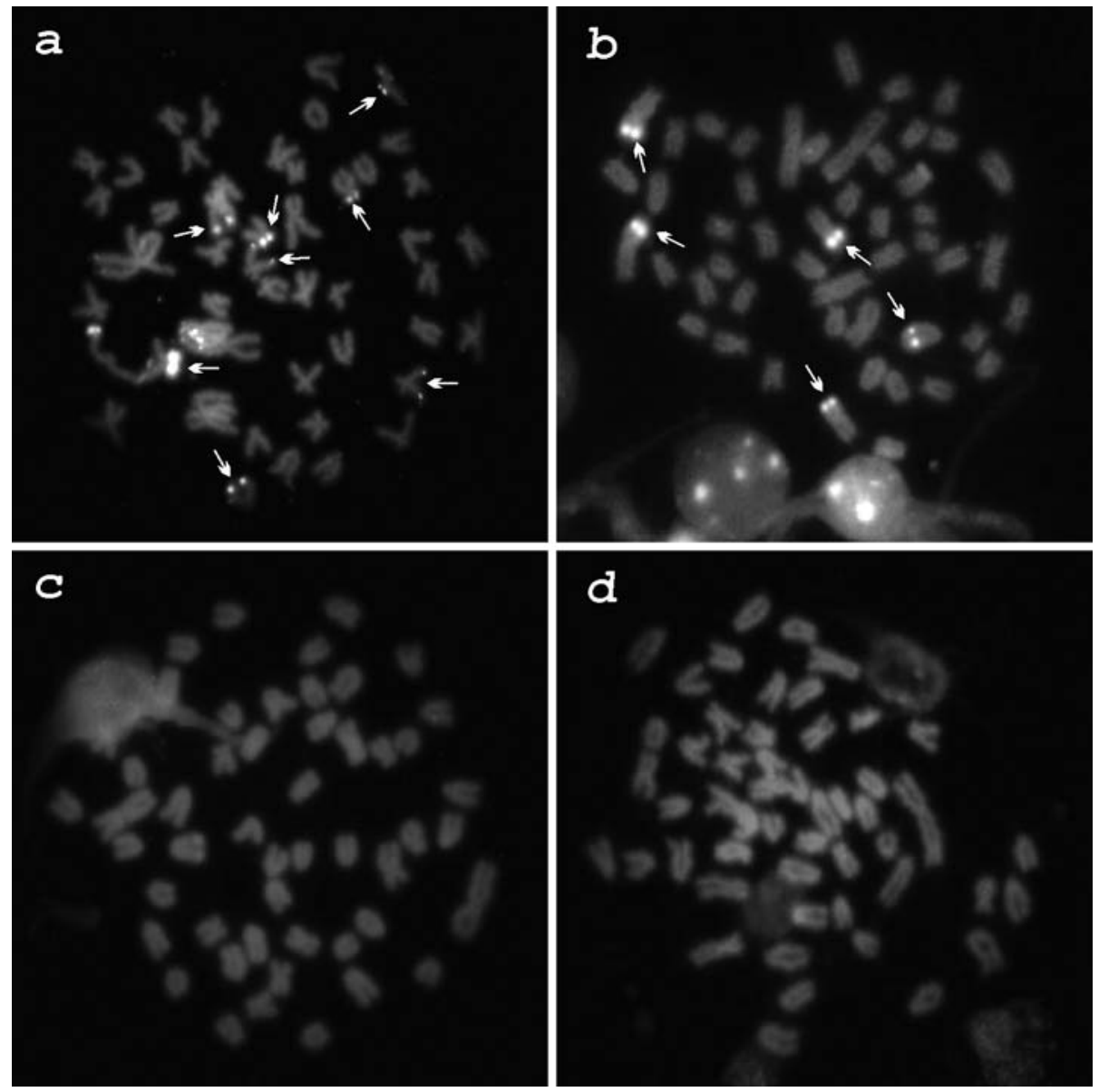

Figure 3 - Fluorescence in situ hybridization with As-51 satellite DNA probe. The arrows indicate these sites in: (a) A. scabripinnis; (b) A. parahybae. In (c) and (d) it is showed lack of signals of the satellite DNA correspondence in A. intermedius and A. giton, respectively.

In A. parahybae, the heterochromatin was distributed in the pericentromeric regions of almost all chromosomes and in the terminal regions of a few ones (Figure 1-b). GC-positive sites were identified in a chromosome pair and in a single homologue of another chromosome pair (Figure 2-b), as in A. scabripinnis. This differences between homologues may be due to uneven exchanges during meiosis. The As-51 satellite DNA probe hybridized to the terminal regions of a few chromosomes (Figure 3-b) and to one interstitial site with an apparent size heteromorphism between the homologues. A. parahybae has been grouped as a subspecies inside the "A. fasciatus" complex until recently. Its taxonomic status was defined by Melo (2001) in a revision of Astyanax species from the Serra dos Órgãos, Paraíba do Sul river basin. It is relevant that other A. fasciatus populations, from the Piracicaba river (Abel et al., 2006) and from the Mogi-Guaçu river basin (Pazza, 2005) also presented such satellite DNA. Thus, its detection in $A$. parahybae could indicate a closer relationship between both species.

Besides very similar karyotypic formulas and scarce heterochromatin distribution, A. giton and A. intermedius presented other chromosomal features which indicate a close cytotaxonomical relationship: both of them did not show any GC-positive (Figure 2-c,d) or AT-positive heterochromatin, neither hybridization with the As-51 satellite DNA probe (Figure 3-c,d). Heterochromatin without GC- or AT-positive clusters is uncommon in fish, but has been observed in Harttia loricariformis (Kavalco et al., 2004b). Besides the macrokaryotypic differentiation, the presence or absence of the As-51 satellite DNA could corroborate the polyphyletism of the genus Astyanax, suggested by Weitzman and Malabarba (1998). Although phylogenetic relationships between these species should be assessed by molecular analyses including several Astyanax species, cytogenetic data could support the hypothesis that A. giton and A. intermedius belong to a clade different from the A. scabripinnis and A. parahybae clade.

Although cytogenetic data are only available for a small number of Astyanax species, the heterochromatin data indicate that at least two distinct Astyanax groups occur in the Paraíba do Sul river basin: one group with few acrocentric chromosomes, As-51 satellite DNA and GCpositive sites, and another group with many acrocentric chromosomes, no GC-positive heterochromatin, neither As-51 satellite DNA. Mestriner et al. (2000) suggested that 
the As-51 DNA distribution pattern found in $A$. scabripinnis and A. fasciatus may be an ancestral feature. The two other species possibly occupy a more derived position. Furthermore, A. scabripinnis showed different number of clusters and distribution patterns of such satellite DNA (Mestriner et al., 2000; Mantovani et al., 2004), as did Astyanax fasciatus (Pazza et al., 2006). The distribution of $5 \mathrm{~S}$ rDNA sites in Astyanax also pointed to the occurrence of two main groups, which is in agreement with the data herein reported. Almeida-Toledo et al. (2002) identified a marker metacentric pair in five Astyanax species. This pair was also observed in A. scabripinnis and A. parahybae, and was absent in A. giton and A. intermedius (Kavalco et al., 2004a). The large number of 5S rDNA sites in the two latter species may reflect their close relationship and their phylogenetic distance from the other species.

\section{Acknowledgements}

The authors wish to thank PhD Paulo A. Buckup for the taxonomic identifications. This work was supported by FAPESP (Proc. 01/00713-0 and 01/05185-5) and CNPq.

\section{References}

Abel LDS, Mantovani M and Moreira-Filho O (2006) Chromosomal distribution of the As51 satellite DNA in two species complexes of the genus Astyanax (Pisces, Characidae). Genet Mol Biol 29:448-452.

Almeida-Toledo LF, Ozouf-Costaz C, Foresti F, Bonillo C, Porto-Foresti F and Daniel-Silva MFZ (2002) Conservation of the 5S-bearing chromosome pair and co-localization with major rDNA clusters in five species of Astyanax (Pisces, Characidae). Cytogenet Genome Res 97:229-233.

Artoni RF and Bertollo LAC (1999) Nature and distribution of constitutive heterochromatin in fishes, genus Hypostomus (Loricariidae). Genetica 106:209-214.

Bertollo LAC, Takahashi CS and Moreira-Filho O (1978) Cytotaxonomic considerations on Hoplias lacerdae (Pisces, Erythrinidae). Genet Mol Biol 1:103-120.

Eigenmann CH (1921) The American Characidae. Mem Mus Comp Zool 23:209-310.

Fernandes CA and Martins-Santos IC (2005) Sympatric occurrence of three cytotypes and four morphological types of $\mathrm{B}$ chromosomes of Astyanax scabripinnis (Pisces, Characiformes) in the River Ivaí Basin, state of Paraná, Brazil. Genetica 124:301-306.

Ferro DAM, Neo DM, Moreira-Filho O and Bertollo LAC (2001) Nucleolar organizing regions, $18 \mathrm{~S}$ and $5 \mathrm{~S}$ rDNA in Astyanax scabripinnis (Pisces, Characidae): Populations distribution and functional diversity. Genetica 110:55-62.

Galetti Jr. PM, Mestriner CA, Venere PC and Foresti F (1991) Heterochromatin and karyotypic reorganization in fish of family Anostomidae (Characiformes). Cytogenet Cell Genet 56:116-121.

Jesus CM, Galetti Jr. PM, Valentini SR and Moreira-Filho O (2003) Molecular characterization and chromosomal localization of two families of satellite DNA in Prochilodus lineatus (Pisces, Prochilodontidae), a species with B chromosomes. Genetica 118:25-32.
Kavalco KF and Moreira-Filho O (2003) Cytogenetical analyses in four species of the genus Astyanax (Pisces, Characidae) from Paraíba do Sul river basin. Caryologia 56:453-461.

Kavalco KF, Pazza R, Bertollo LAC and Moreira-Filho O (2004a) Gene mapping of 5S rDNA sites in eight fish species from the Paraíba do Sul river basin, Brazil. Cytogenet Genome Res 106:107-110.

Kavalco KF, Pazza R, Bertollo LAC and Moreira-Filho O (2004b) Heterochromatin characterization of four fish species of the family Loricariidae (Siluriformes). Hereditas 141:237-242.

Kavalco KF, Pazza R, Bertollo LAC and Moreira-Filho O (2005) Molecular cytogenetics of Oligosarcus hepsetus (Teleostei, Characiformes) from two Brazilian locations. Genetica 124:85-91.

Levan A, Fredga K and Sandberg AA (1964) Nomenclature for centromeric position on chromosomes. Hereditas 52:201220.

Mantovani M, Abel LDS, Mestriner CA and Moreira-Filho O (2000) Accentuated polymorphism of heterochromatin and nucleolar organizer regions in Astyanax scabripinnis (Pisces, Characidae): Tools for understanding karyotypic evolution. Genetica 109:161-168.

Mantovani M, Abel LDS, Mestriner CA and Moreira-Filho O (2004) Evidence of the differentiated structural arrangement of constitutive heterochromatin between two populations of Astyanax scabripinnis (Pisces, Characidae). Genet Mol Biol 27:536-542.

Margarido VP and Galetti Jr. PM (1999) Heterochromatin patterns and karyotype relationships within and between the genera Brycon and Salminus (Pisces, Characidae). Genet Mol Biol 22:357-361.

Margarido VP and Galetti Jr. PM (2000) Amplification of a GC-rich heterochromatin in the freshwater fish Leporinus desmotes (Characiformes, Anostomidae). Genet Mol Biol 23:569-573.

Martins C and Galleti Jr. PM (1999) Chromosomal localization of 5S rDNA genes in Leporinus fish (Anostomidae, Characiformes). Chromosome Res 7:363-367.

Mayr B, Kalat M and Ràb P (1985) Localization of NORs and counterstain-enhanced fluorescence studies in Perca fluviatilis (Pisces, Percidae). Genetica 67:51-56.

Melo FAG (2001) Revisão taxonômica das espécies do gênero Astyanax Baird e Girard, 1854 (Teleostei, Characiformes, Characidae) da região da Serra dos Órgãos. Arq Mus Nac RJ 59:1-46 (Abstract in English).

Mestriner CA, Galetti Jr PM, Valentini SR, Ruiz IRG, Abel LDS, Moreira-Filho O and Camacho JPM (2000) Structural and functional evidence that B chromosome in the characid fish Astyanax scabripinnis is an isochromosome. Heredity 85:1-9.

Molina W, Schmid M and Galetti Jr. PM (1998) Heterochromatin and sex chromosomes in the Neotropical fish genus Leporinus (Characiformes, Anostomidae). Cytobios 94:141-149.

Moreira-Filho O and Bertollo LAC (1991). Astyanax scabripinnis (Pisces, Characidae): A species complex. Genet Mol Biol 14:331-357.

Pazza R (2005) Contribuição citogenética à análise da biodiversidade em Astyanax fasciatus (Pisces, Characidae). PhD. Thesis, Universidade Federal de São Carlos, São Carlos, 98 pp. Abstract in English. http://www.bdtd.ufscar.br/tde arquivos/16/TDE-2005-05-16T08:29:20Z-664/Publico/Dis sCG.pdf. 
Pazza R, Kavalco KF, Almeida-Toledo LF and Bertollo LAC (2005) Hoplosternum littorale (Teleostei, Callichthyidae) from a Coastal River basin in Brazil - Cytogenetic analysis and gene mapping of $5 \mathrm{~S}$ and $18 \mathrm{~S}$ rDNA. Caryologia 58:339-344.

Pazza R, Kavalco KF and Bertollo LAC (2006) Chromosome polymorphism in Astyanax fasciatus (Teleostei, Characidae). 1. Karyotype analysis, Ag-NORs and mapping of the $18 \mathrm{~S}$ and $5 \mathrm{~S}$ ribosomal genes in sympatric karyotypes and their possible hybrid forms. Cytogenet Genome Res 112:313-319.

Phillips R and Hartley SE (1988) Fluorescent banding patterns of the chromosomes of the genus Salmo. Genome 30:193-197.

Pinkel D, Straume T and Gray JW (1986) Cytogenetic analysis using quantitative, high-sensitivity, fluorescence hybridization. Proc Natl Acad Sci 83:2934-2938.

Reis RO, Kullander SO and Ferraris Jr. CJ (2003) Check List of the Freshwater Fishes of South and Central America. EDIPUCRS, Porto Alegre, 742 pp.

Schmid M (1980) Chromosome banding in Amphibia. IV. Differentiation of GC- and AT-rich chromosome region in Anura. Chromosoma 77:83-103.

Schmid M and Guttenbach M (1988) Evolutionary diversity of reverse (R) fluorescent chromosome bands in vertebrates. Chromosoma 97:101-114.
Schweizer D (1980) Simultaneus fluorescent staining of R bands and specific heterochromoatic regions (DA-DAPI bands) in human chromosomes. Cytogenet Cell Genet 27:190-193.

Sola L, Rossi AR, Iaselli V, Rash EM and Mônaco PJ (1992) Cytogenetics of bisexual/unisexual species of Poecilia. II. Analysis of heterochromatin and nucleolar organizer regions in Poecilia mexicana mexicana by C-banding and DAPI, quinacrine, chromomycin $\mathrm{A}_{3}$ and silver staining. Cytogenet Cell Genet 60:229-235.

Souza IL, Moreira-Filho O and Galetti Jr. PM (1996) Heterochromatin differentiations in the characid fish Astyanax scabripinnis. Genet Mol Biol 19:405-410.

Sumner AT (1972) A simple techinique for demonstrating centromeric heterocromatin. Exp Cell Res 75:304-306.

Vicente VE, Bertollo LAC, Valentini SR and Moreira-Filho O (2004) Origin and Differentiation of a sex chromosome system in Parodon hilarii (Pisces, Parodontidae). Satellite DNA, G- and C-banding. Genetica 119:115-120.

Weitzman SH and Malabarba LR (1998) Perspectives about the phylogeny and classification of the Characidae (Teleostei, Characiformes). In: Malabarba LR, Reis ER, Vari RP, Lucena ZMS and Lucena CA (eds) Phylogeny and Classification of Neotropical Fishes. EDIPUCRS, Porto Alegre, pp 161-170.

Associate Editor: Fausto Foresti 